Tarbawi: Jurnal Ilmu Pendidikan p-ISSN:1858-1080 | e-ISSN: 2615-6547

Vol. 16, No. 2, Desember 2020, $154-159$

\title{
Pengaruh Model Pembelajaran Picture and Picture Terhadap Hasil Belajar Matematika Siswa pada Pokok Bahasan Teorema Phytagoras
}

\author{
Loria Wahyuni, Nining Huriyati \\ STKIP Muhammadiyah Sungai Penuh \\ E-mail: loriawahyuni73@gmail.com
}

\begin{abstract}
Abstrak. Berdasarkan hasil observasi yang dilakukan sikap tanggung jawab siswa dalam pembelajaran masih kurang dalam hal menyelesaikan tugas individu. Model pembelajaran konvensional yang digunakan oleh guru kurang sesuai dengan spesifikasi materi pelajaran, sehingga pembelajaran yang dilakukan kurang memberi kesempatan seluas-luasnya bagi siswa untuk aktif mengkonstruksikan pengetahuan dan keterampilannya serta kurang mempertimbangkan hakikat gaya belajar siswa. Berdasarkan hal tersebut maka penulis ingin mengadakan penelitian dengan tujuan untuk melihat pengaruh model pembelajaran picture and picture yang diharapkan dapat meningkatkan hasil belajar matematika siswa dan mengatasi masalah tersebut di atas. Jenis penelitian ini adalah penelitian eksperimen. Dimana Populasi dalam penelitian ini adalah seluruh siswa Kelas VIIIA, VIII B Dan VIII C yang berjumlah 3 kelas dengan jumlah siswa sebanyak 62 siswa dengan kelas eksperimen adalah kelas VIII A dan keas control adalah VIII C. Teknik analisis data yang digunakan meliputi uji normalitas, homogenitas, kesamaan rata-rata dan uji hipotesis. Berdasarkan hasil penelitian dapat disimpulkan terdapat pengaruh model pembelajaran picture and picture terhadap hasil belajar matematika siswa pada pokok bahasan Teorema Phytagoras. Selanjutnya rekomendasi atau saran untuk penelitian berikutnya adalah supaya menggunakan model pembelajaran picture and picture disertai dengan media animasi yang bias membuat peserta didik menjadi lebih tertarik dalam megikuti pembelajaran matematika.
\end{abstract}

Kata kunci: Picture and Picture, Hasil Belajar, Teorema Phytagoras

\begin{abstract}
Based on observations made by the the attitude of student responsibility in learning is still lacking in terms of completing individual tasks. Most of the conventional learning models used by teachers are not relevant with the specifications of the subject matter, so that the learning carried out does not provide the widest possible opportunity for students to actively construct their knowledge and skills and does not consider the nature of student learning styles. Based on this, the authors wanted to conduct research with in order to see effectthe picture and image learning model which is expected to improve student mathematics learning outcomes and overcome the problems mentioned above. This type of research is experimental research. Where the population in this study were all students of Class VIIIA, VIII $B$ and VIII $C$ as measured by 3 classes with a total of 62 students. The experimental class was class VIII $A$ and the control class was VIII C.The data analysis technique used includes normality test, homogeneity, average similarity and hypothesis testing.Based on the results it can interfere with the effect of learning models of pictures and images on student mathematics learning outcomes on the subject of the Pythagorean Theorem.Furthermore, the recommendation or suggestion for the next research is to use the picture and picture learning model accompanied by animation media that can make students more interested in participating in mathematics learning.
\end{abstract}

Keywords: Pictures and Picture, Achievement, Pythagorean Theorem 


\section{PENDAHULUAN}

Paradigma pembelajaran telah bergeser dari paradigma lama (behavioristik) ke paradigma baru (konstruktivistik). Perubahan paradigma belajar tersebut terjadi perubahan fokus yang selama ini pembelajaran yang berfokus pada guru dan dosen (teachercentered) kepada pembelajaran yang berfokus pada peserta didik (student centered). Pergeseran paradigma ini guna untuk menyesuaikan kurikulum yang berlaku pada saat ini. Namun demikian, behavioristik bukan ditinggalkan sama sekali, akan tetapi behavioristik akan masih diterapkan pada karyawan industri, karyawan kantor, militer dan lain sebagainya untuk menciptakan perilaku yang seragam.

Temuan di lapangan pada salah satu SMP yang ada di Kabupaten Kerinci, sikap tanggung jawab siswa dalam pembelajaran masih kurang dalam hal menyelesaikan tugas individu diantaranya masih ada siswa yang menyontek. Model pembelajaran konvensional yang digunakan oleh guru sebagian besar kurang sesuai dengan spesifikasi materi pelajaran, sehingga pembelajaran yang dilakukan kurang memberi kesempatan seluas-luasnya bagi siswa untuk aktif mengkonstruksikan pengetahuan dan keterampilannya. Aktivitas siswa untuk bertanya, menjawab dan mengajukan pendapat, sangat kurang pada saat pembelajaran berlangsung, sehingga nilai ujian mid semester genap matematika siswa tahun pelajaran 2018/2019 masih dibawah Kriteria Ketuntasan Minimal (KKM).

Seorang guru harus mempunyai kemampuan mengajar sesuai dengan bidang studinya, contohnya seorang guru matematika mampu menggunakan suatu model dalam bidang matematika dengan baik dan benar karena ia menguasai tekniknya. Karena model pembelajaran merupakan hal yang paling lebih terfokus terhadap hasil pembelajaran matematika diantara banyak pengaruh lain. Mengingat pentingnya peranan matematika yang berfungsi sebagai penunjang yang dapat dipergunakan dalam berbagai ilmu pengetahuan dan kehidupan, maka para siswa perlu memiliki penguasaan matematika yang memadai sehingga perlu di cari solusi untuk meningkatkan hasil belajar siswa.

Berdasarkan permasalahan yang telah dikemukakan dibutuhkan suatu model pembelajaran, agar proses pembelajaran matematika lebih menyenangkan, bermanfaat dan diharapkan dapat meningkatkan pemahaman serta bias mengaktifkan siswa dalam pembelajaran. Model mengajar yang baik adalah model yang dapat menumbuhkan minat belajar siswa. Model pembelajaran yang dianggap mampu mengantisipasi kelemahan model pembelajaran konvensional adalah dengan menggunakan model pembelajaran yang pendekatannya olah piker logis siswa, diantaranya adalah model pembelajaran picture and picture. Menurut Supriyono dalam Farida (2016) menerangkan bahwa model pembelajaran picture and picture merupakan pembelajaran yang menggunakan gambar sebagai media pembelajaran. Dalam penggunaan media pada model ini yaitu dimana gambar yang diberikan pada siswa harus dipasangkan atau diurutkan sehingga menjadi urutan yang logis. Dengan diterapkan model ini siswa akan lebih aktif dan pembelajaran yang dilaksanakan berpusat pada siswa (Yanti, Laswadi, Ningsih, Putra, \& Ulandari, 2019).

Hal ini sejalan dengan penelitian yang dilakukan oleh Ayu (2017) bahwa penerapan Model Pembelajaran Picture and Picture Berorientasi Pendidikan Karakter berpengaruh terhadap motivasi belajar. Berdasarkan fenomena tersebut, penulis tertarik untuk mengadakan penelitian tentang pengaruh model pembelajaran picture and picture terhadap hasil belajar matematika siswa pada materi Teorema Phytagoras di kelas VIII. Tujuan khusus dari penelitian ini adalah untuk melihat ada atau tidaknya pengaruh model pembelajaran picture and picture terhadap hasil belajar matematika siswa. 


\section{METODOLOGI}

Jenis penelitian ini adalah quasi eksperimen dimana pada kelompok ini peneliti sengaja memberikan perlakuan dengan menggunakan model picture and picture (Suryabrata, 2010).

\section{Tabel 1 Rancangan Penelitian}

\begin{tabular}{ccc}
\hline Kelas & Treatment & Posttest \\
\hline Kontrol & $\mathrm{X} 1$ & $\mathrm{~T} 1$ \\
\hline Eksperimen & $\mathrm{X} 2$ & $\mathrm{~T} 2$ \\
\hline
\end{tabular}

Keterangan:

T1 : Nilai posttest setelah diajar menggunakan model pembelajarankonvensional.

T2 : Nilai posttest setelah diajar menggunakan model pembelajaran Picture and Picture

$\mathrm{X} 1$ : Kelas yang diajarkan tanpa menggunakan model pembelajaran picture and picture.

$\mathrm{X} 2$ : Kelas yang diajarkan denganmenggunakan model pembelajaran picture and picture.

Populasi dalam penelitian ini adalah seluruh siswa kelas VIII sedangkan sampel adalah diambil secara random sampling. Kelas yang terpilih adalah kelas VIIIA sebagai kelas eksperimen dengan jumlah siswa 20 orang dan kelas VIIIC sebagai kelas control dengan jumlah siswa 20 orang.

Instrumen yang digunakan dalam penelitian ini yaitu tes hasil belajar yang berupa soal yang berbentuk essay yang terdiri dari 15 soal. Ada pun indicator dalam soal ini adalah meliputi (1) menemukan Teorema Pythagoras (2) menghitung panjang sisi segitiga siku-siku jika dua sisi lain diketahui (3) menemukan kebalikan teorema pythagoras (4) mengenal tripel Pythagoras (5) menghitung perbandingan sisi sisi segitiga siku-siku dengan sudut istimewa.

Analisis data yang dilakukan meliputi uji normalitas, uji kesamaan rata-rata, uji homogenitas dan uji hipotesis dengan menggunakan uji-t. Analisis data yang dilakukan menggunakan bantuan aplikasi SPSS.

\section{TEMUAN}

Setelah dilakukan tes hasil belajar matematika siswa terhadap kelas eksperimen dan kelas kontrol, hasil tes tersebut dianalisis dengan menghitung rata-rata hasil belajar matematika siswa berdasarkan kelas.

Untuk kelas eksperimen diperoleh hasil belajar matematika yang lebih tinggi dibandingkan kelas kontrol. Hal ini dibuktikan dengan analisis data postes kelas eksperimen menunjukkan angka 81,50, dan kelas kontrol 72,00. 


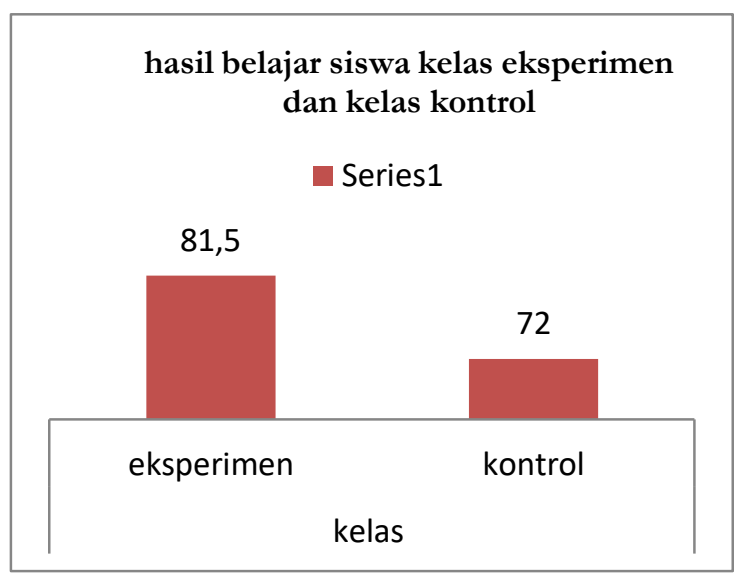

Berdasarkan grafik diagram di atas dapat dilihat bahwa rata-rata nilai kelas eksperimen 81,50 sedangkan kelas kontrol 72,00 hal ini menunjukkan bahwa kelas eksperimen dengan pembelajaran menggunakan model pembelajaran picture and picture memberi kontribusi yang sangat baik dengan selisih mencapai 9,5. Karena pembelajran yang diterapkan menggunakan media yang cukup menunjang sehingga dapat meningkatkan keaktifan dan hasil belajar matematika siswa.

Tabel 2 Hasil Uji Normalitas Nilai Postes Siswa

\begin{tabular}{cccccccc}
\hline \multirow{2}{*}{ Kelas } & \multicolumn{3}{c}{ Kolmogorov-Smirnov $^{a}$} & \multicolumn{3}{c}{ Shapiro-Wilk } \\
\cline { 2 - 8 } & Statistic & Df & Sig. & Statistic & df & Sig. \\
\hline \multirow{2}{*}{ Nilai } & Eksperimen & .119 & 20 & $.200^{*}$ & .942 & 20 & .262 \\
\cline { 2 - 8 } & Kontrol & .176 & 20 & .108 & .922 & 20 & .110 \\
\hline
\end{tabular}

Berdasarkan hasil uji Kolmogorov-Smirnov pada Tabel di atas diperoleh nilai signifikansi atau nilai p-value semua kelas lebih besar dari nilai alpha $(0,05)$ maka dapat dikatakan nilai postes siswa pada sampel penelitian tersebut berdistribusi normal.

Tabel 3 Hasil Uji Homogenitas Nilai Postes Siswa

\begin{tabular}{cccc}
\hline Levene Statistic & df1 & df2 & Sig. \\
\hline .009 & 1 & 38 & .924 \\
\hline
\end{tabular}

Dari output di atas dapat diketahui nilai signifikansi dari nilai postes siswa $=0,924$ atau $p$ value $>$ alpha $=0,05$. Maka dapat disimpulkan bahwa data nilai postes siswa homogen.

Hasil uji normalitas dan uji homogenitas nilai postes pada penelitian ini menunjukkan data yang berdistribusi normal dan data kelas sampel mempunyai varians yang homogen. Oleh sebab itu data memenuhi syarat untuk dilakukan uji hipotesis menggunakan uji-t.

Sebelum dilakukan uji hipotesis data hasil belajar matematika siswa dilakukan uji normalitas dan uji homogenitas seterusnya data tersebut diolah menggunakan uji-t.setelah data diolah sehingga diperoleh nilai signifikansi ( $\mathrm{p}$-value) $=0,003<\propto=0,05$ sehingga dapat disimpulan bahwaterdapat Pengaruh model pembelajaran picture and pictureterhadap hasil belajar matematika siswa pada pokok bahasan teorema phytagoras di kelas VIII (Delapan) SMP Negeri 7 Kerinci. 


\section{DISKUSI}

Nilai hasil belajar atau nilai postes siswa pada kelas eksperimen rata-ratanya lebih tinggi jika dibandingkan dengan kelas kontrol. Karena pada kelas eksperimen siswa diberikan perlakuan atau diajarkan dengan model pembelajran picture and picture sedangkan pada kelas contr ol diajarkan dengan menggunakan model pembelajaran konvensional.

Model pembelajaran picture and picture adalah suatu model pembelajaran yang menggunakan gambar dan dipasangkan/diurutkan menjadi urutan yang logis. Model pembelajaran picture and picture ini mengandalkan gambar sebagai media dalam proses pembelajaran. Gambar-gambar ini menjadi factor utama dalam proses pembelajaran. Sehingga sebelum proses pembelajaran guru sudah menyiapkan gambar yang akan ditampilkan baik dalam bentuk kartu atau dalam bentuk karta dalam ukuran besar.

Menurut Utami (2013) Kelebihan dan kekurangan Model Pembelajaran Picture And Picture adalah (1) Materi yang diajarkan lebih terarah karena pada awal pembelajaran guru menjelaskan kompetensi yang harus dicapai dan materi secara singkat terlebih dahulu. (2) Siswa lebih cepat menangkap materi ajar karena guru menunjukkan gambar-gambar mengenai materi yang dipelajari. (3) Dapat meningkat daya nalar atau daya pikir siswa karena siswa disuruh guru untuk menganalisa gambar yang ada. (4) Dapat meningkatkan tanggung jawab siswa, sebab guru menanyakan alasan siswa mengurutkan gambar. (5) Pembelajaran lebih berkesan, sebab siswa dapat mengamati langsung gambar yang telah dipersiapkan oleh guru.

Hal tersebut di atas juga sejalan dengan hasil penelitian yang dilakukan oleh Wiranata (2014) dengan judul penelitian "Pengaruh Penggunaan Model Pembelajaran Picture And Picture Terhadap Hasil Belajar Perubahan Lingkungan Fisik Pada Kelas IV SDN 80/1 Muara Bulian" Setelah dilakukan penelitian diketahui terdapat pengaruh penggunaan model pembelajaran picture and picture terhadap hasil belajar perubahan lingkungan fisik pada taraf kepercayaan $95 \%$, yang berarti Ha diterima dan Ho ditolak. Hasil belajar yang menggunakan model pembelajaran picture and picture lebihtinggidaripada yang tidakmenggunakan model pembelajranpicture and picture. Dimana rata-rata hasilbelajarsiswa yang menggunakan model pembelajaranpicture and picture (Kelas IV A) 8,75 sedangkanhasilbelajarsiswa yang tidakmenggunakanmodel pembelajaranpicture and picture (Kelas IV B) 7,96. Sejalan juga dengan penelitian yang dilakukan oleh Sipahutar (2018) dengan hasil penelitiannya yaitu ada Pengaruh Penggunaan Model Pembelajaran picture and picture terhadap Hasil Belajar Ekonomi Siswa Materi Pengangguran Kelas XI IPS SMA Negeri 1 Sibabangun.

Berdasarkan hasil penelitian yang telah peneliti lakukan beserta dengan penelitian yang relevan tersebut di atas dapat dilihat bahwa model pembelajaran picture and picture memberikan pengaruh yang signifikan terhadap hasil belajar. model pembelajaran picture and picture dapat meningkatkan keaktifan siswa. Siswa menjadi lebih aktif dalam mengikuti proses belajar mengajar matematika. Hal ini juga didukung dengan media bergambar yang disajikan pada pada bentuk gambar dan video sehingga siswa menjadi lebih aktif mengamati gambar yang telah disajikan guru, selain itu siswa diajak pada pemecahan masalah yang berhubungan dengan kegiatan sehari-hari sehingga masalah yang disajikan membuat siswa menjadi tertarik untuk mencari solusinya (Putra, Ulandari, \& Sepnila, 2020). Sehingga pola pembelajaran seperti ini menjadi sangat strategis untuk meningkatkan pemahaman siswa terhadap tujuan dari pembelajaran matematika. Mereka memahami wawasan dari operasional materi, materi ini juga menjadi pacuan untuk meningkatkan daya serap siswa.

\section{SIMPULAN}

Berdasarkan tes akhir yang peneliti lakukan dapat disimpulkan yaitu terdapat pengaruh model pembelajaran picture and picture terhadap hasil belajar matematika siswa pada materi teorema phytagoras kelas VIII SMP Negeri 7 Kerinci. Selanjutnya rekomendasi atau saran untuk 
penelitian berikutnya adalah supaya menggunakan model pembelajaran picture and picture disertai dengan media animasi yang bias membuat peserta didik menjadi lebih tertarik dalam megikuti pembelajaran matematika.

\section{REFERENSI}

Ayu, S. P. N., Wayan, R. N., \& Desi, T. N. K. (2017). Pengaruh Model Pembelajaran Picture and Picture Berorientasi Pendidikan Karakter Terhadap Motivasi Belajar IPS Siswa Kelas V. Journal of Education Technology, 3(1), 1-8.

Farida, A. F. D. (2016). Pengaruh Model Picture and Picture terhadap Kemampuan Mendiskripsikan Proses Daur Air dan Kegiatan Manusia yang dapat Mempengaruhinya Siswa Kelas V SDN Taman Kota Kediri Tahun Ajaran 2014-2015. Skripsi. JawaTimur: FKIP Universitas Nusantara PGRI Kediri.

Purwanto. (2013). Evaluasi basil Belajar. Yogyakarta: Pustaka Pelajar.

Riduwan. (2010). Metode dan Teknik. Menyusun Tesis. Bandung: Alfabeta.

Sipahutar, J. (2018). Pengaruh Penggunaan Model Pembelajaran Picture and Picture terhadap Hasil Belajar Ekonomi Siswa Materi Pengangguran Kelas XI IPS SMA Negeri 1 Sibabangun. Jurnal MISI Institut Pendidikan Tapanuli Selatan, (1), 105-111.

Suryabrata, S. (2010). MetodePenelitian. Jakarta: Raja Grafindo.

Taniredja, T. \& Mustafidah, H. (2011). Penelitian Kuantitatif. Bandung: Alfabeta.

Utami, E. (2013). Penggunaan Model Pembelajaran Picture and Picture untuk Meningkatkan Keaktifan Belajar Siswa Pada Pembelajaran Matematika di Kelas V SD Islam Terpadu Arofah 1 Boyolali Tahun Ajaran 2012/2013. Skripsi. Jawa Timur: FKIP Universitas Muhammadiyah Surakarta.

Wiranata, S. E. (2014). Pengaruh Penggunaan Model Pembelajaran Picture and Picture terhadap Hasil Belajar Perubahan Lingkungan Fisik pada Kelas IV SDN 80/I Muara Bulian. Skripsi. Jambi: FKIP Unja.

Putra, A., Ulandari, N., \& Sepnila, D. (2020). Penerapan Model Pembelajaran Quick on The Draw dengan Masalah Open-Ended terhadap Pemahaman Konsep Matematis Siswa. Jurnal Pendidikan Matematika Raflesia, 5(1), 1-16. doi:10.33449/jpmr.v5i1.10632

Yanti, R., Laswadi, L., Ningsih, F., Putra, A., \& Ulandari, N. (2019). Penerapan Pendekatan Saintifik Berbantuan Geogebra dalam Upaya Meningkatkan Pemahaman Konsep Matematis Siswa. AKSIOMA: Jurnal Matematika dan Pendidikan Matematika, 10(2), 180-194. doi:10.26877/aks.v10i2.4399 